\title{
Efficacy of Origanum essential oils for inhibition of potentially pathogenic fungi
}

\author{
Nadábia Almeida B. Souza ${ }^{1}$, Edeltrudes de Oliveira Lima², Diego Nunes Guedes², Fillipe de Oliveira \\ Pereira $^{1}$, Evandro Leite de Souza ${ }^{3, *}$, Frederico Barbosa de Sousa ${ }^{4}$
}

\begin{abstract}
${ }^{1}$ Laboratory of Mycology, Department of Pharmaceutical Sciences, Health Sciences Center, Federal University of Paraiba, João Pessoa, Brazil; ' ${ }^{2}$ Department of Physiology and Pathology, Health Sciences Center, Federal University of Paraiba, João Pessoa, Brazil; ${ }^{3}$ Laboratory of Food Microbiology, Department of Nutrition, Health Sciences Center, Federal University of Paraiba, João Pessoa, Brazil; ${ }^{4}$ Laboratory of Microscopy and Biological Image, Health Sciences Center, Federal University of Paraíba, João Pessoa, Brazil
\end{abstract}

\begin{abstract}
This study aimed to assess the efficacy of $O$. vulgare $L$. and $O$. majorana $L$. essential oil in inhibiting the growth and survival of potentially pathogenic fungal strains and also sought to evaluate the possible mechanisms involved in the establishment of the antifungal property of the tested essential oils through assays of osmotic stability and morphogenesis. Test strains included in this study were Candida albicans ATCC 7645, C. tropicalis LM-14, C. krusei LM-09, Cryptococcus neoformans FGF-5, Aspergillus flavus LM-02, A. fumigatus IPP-21, T. rubrum ATCC 28184, T. mentagrophytes LM-64, Microsporum gypseum ATCC 184, M. canis LM-36 and Cladosporium herbarium ATCC 26362. O. vulgare essential oil presented a MIC value of $80 \mu \mathrm{L} / \mathrm{mL}$, while for $O$. majorana this was $160 \mu \mathrm{L} / \mathrm{mL}$. C. krusei LM-09 was the only strain resistant to all assayed concentrations of both essential oils. $O$. vulgare and $O$. majorana essential oil at their MIC values provided a cidal effect against C. albicans ATCC 7645 after $4 \mathrm{~h}$ of exposure. $O$. vulgare essential oil at $80 \mu \mathrm{L} / \mathrm{mL}$ exhibited $100 \%$ inhibition of the radial mycelia growth of T. rubrum ATCC 28184 and M. canis LM-36 for 14 days. Assayed fungus strain protected by sorbitol (osmo-protectant agent) grew in media containing higher concentrations of $O$. vulgare and $O$. majorana essential oil in comparison to media without sorbitol, suggesting some specificity of these essential oils for targeting cell wall in the fungi cell. Main morphological changes observed under light microscopy provided by the essential oil of $O$. vulgare in A. flavus LM- 02 were decreased conidiation, leakage of cytoplasm, loss of pigmentation and disrupted cell structure indicating fungal wall degeneration. These results suggest that essential oils from Origanum could be regarded as a potential antifungal compound for controlling the growth of pathogen fungi and the occurrence of mycoses.
\end{abstract}

Uniterms: Essential oil. Pathogen fungi. Origanum sp./antifungal property.

O objetivo deste estudo foi observar a eficácia do óleo essencial de $O$. vulgare L. e O. majorana $L$. na inibição do crescimento e sobrevivência de cepas de fungos potencialmente patogênicas, bem como avaliar os possíveis mecanismos envolvidos no estabelecimento da propriedade antifúngica dos óleos essenciais testados através do ensaio de estabilidade osmótica e morfogênese. As cepas fúngicas utilizadas neste estudo foram Candida albicans ATCC 7645, C. tropicalis LM-14, C. krusei LM-09, Cryptococcus neoformans FGF-5, Aspergillus flavus LM-02, A. fumigatus IPP-21, T. rubrum ATCC 28184, T. mentagrophytes LM-64, Microsporum gypseum ATCC 184, M. canis LM-36 e Cladosporium herbarium ATCC 26362. O óleo essencial de $O$. vulgare apresentou valor de CIM de $80 \mu \mathrm{L} / \mathrm{mL}$, enquanto o óleo essencial de O. majorana apresentou valor de CIM de $160 \mu \mathrm{L} / \mathrm{mL}$. C. krusei LM-09 apresentouse como a única cepa resistente a todas as concentrações ensaiadas de ambos os óleos essenciais. Os óleos essenciais testados quando ensaiadas em seu valor de CIM causaram um efeito fungicida contra $C$. albicans ATCC 7645 após $4 \mathrm{~h}$ de exposição. O óleo essencial de $O$. vulgare na concentração de $80 \mu \mathrm{L} /$ mLexibiu uma total inibição do crescimento micelial radial de T. rubrum ATCC 28184 e M. canis LM-36

\footnotetext{
*Correspondence: E. L. Souza. Laboratório de Microbiologia de Alimentos, Departamento de Nutrição, Universidade Federal da Paraíba. Cidade Universitária, Campus I, 58059-900 - João Pessoa - PB, Brasil. E-mail: evandroleitesouza@ccs.ufpb.br
} 


\begin{abstract}
ao longo de 14 dias. As cepas fúngicas ensaiadas quando tratadas com sorbitol (agente osmo-protetor) foram capazes de crescer em meio adicionado de mais altas concentrações dos óleos essenciais quando comparados ao meio não adicionado de sorbitol, sugerindo especificidade destes produtos a parede celular como alvo na célula fúngica. As principais alterações causadas pelo óleo essencial de $O$. vulgare sobre a morfologia de A. flavus LM-02 foram diminuída conidiação, perda de citoplasma, perda de pigmentação e ruptura da estrutura celular indicando degeneração da parede celular fúngica. Estes resultados sugerem que óleos essenciais de espécies de Origanum poderiam ser considerados como potenciais antifúngicos para o controle de fungos patógenos e ocorrência de micoses.
\end{abstract}

Unitermos: Óleo essencial. Patógenos fúngicos. Origanum sp./propriedade antifúngica.

\section{INTRODUCTION}

Over recent years, the incidence of important infections caused by fungi has increased. Opportunistic mycoses attack mainly immunologically suppressed individuals where this suppression is mainly secondary to degenerative diseases (e.g. cancer, diabetes), use of immunological suppressors or antibiotic therapy (Moellering Jr. et al., 2007). Most current antifungal drugs are either toxic (e.g. amphotericin B) or fungistatic (e.g. azoles) and new compounds have been actively sought (Frost et al., 1995).

Candida and Criptococcus genus are known as the yeasts most frequently involved in the etiology of mycotic infections (Lima et al., 2006). Trichophyton, Microsporum and Epidermophyton have the ability to invade keratinized tissues, such as hair, skin or nails, of humans causing dermatophytosis including tinea corporis, tinea pedis and onychomycosis (Weitzman, Summerbell, 1995; Koroishi et al., 2008). Aspergillus flavus and A. parasiticus causes different clinical manifestations of human aspergillosis such as cutaneous aspergillosis, aspergillar otomycosis, aspergillar onychomycosis, invasive lung aspergillosis and aspergillar sinusitis (Dubey et al., 2006).

The advent and widespread use of synthetic antimicrobials in the last century led to a lack of interest in plants as natural sources for antimicrobial drugs (Cowan, 1999). In recent years however, the situation has changed and the systematic screening of the biological interaction between microorganisms and plant products has been recognized as a valuable source of several compounds able to control the survival of pathogen microorganisms (Al-Fatimi et al., 2007). An extensive body of research has demonstrated that essential oils and their main components possess a wide spectrum of biological activity, which may be of great importance in several fields, from food chemistry to pharmaceutics (Knowles et al., 2000; Cristiani et al., 2007).

Several plant families, especially the Lamiaceae, present prominent amounts of essential oil (yield $>2 \%$ ) (Baser, 1993; Baser, 1994). Given their broad variety of chemical characteristics and aroma, different species and biotypes of Origanum are widely used by the pharmaceutical and cosmetic industries, as a food flavor, for fragrance in perfumes and in alcoholic beverages (Sivropoulou et al., 1996; Novak et al., 2003; Aligianis et al., 2001). The Origanum species grow abundantly on stony slopes and rocky mountain areas at a wide range of altitudes (0-400 m) (Sahin et al., 2004).

$O$. vulgare L. (oregano) and O. majorana L. (marjoram) besides over fifty other types of the Oregano genus have been used in folk medicine to treat many illnesses as a spasmodic, antimicrobial, digestive, expectorant and aromatic for whooping and convulsive coughs (Dorman, Deans, 2000; Novak et al., 2003). Some studies have found interesting antimicrobial activity in Origanum species, while $O$. vulgare and $O$. majorana have shown positive results in inhibiting the growth of pathogen microorganis$\mathrm{ms}$ and in the synthesis of microbial metabolites (Marino et al., 2001; Baydar et al., 2004).

The fungal cell wall acts as a protective barrier, prevents osmotic bursting from protoplast turgor and confers shape. The cell wall consists of many macromolecules such as $\beta$-glucans, chitin mannoproteins and other proteins. Many of these macromolecules are essential to the fungi and enzymes that synthesize these constituents could be important antifungal targets (Yamagushi et al., 1982; Varona et al., 1983). Damage to essential cell wall components by antifungal agents will lyse cells in the absence of an osmo-protectant, but cells will continue to growth if a suitable stabilizer is present in the medium. Reiss et al. (1992) and Frost et al. (1995) found that antifungal-treated fungi were viable if broth cultures were protected with sorbitol, but lysed if plated out on agar without osmotic support. According to these authors, assays of osmotic stability have been applied in fungi for assessing the mode of action of classical or emerging antibiotics. The sorbitol assay is claimed to be compatible with a range of natural products and pure chemicals (Kirsch et al., 1986).

This study aimed to evaluate the efficacy of $O$. vulgare and $O$. majorana essential oils in inhibiting the 
growth/survival of fungi, including moulds and yeasts, recognized as potential etiological agents of human mycosis. The investigation also sought to suggest possible mechanisms involved in the establishment of the antifungal property of the tested essential oils through the assay of osmotic stability and morphogenesis.

\section{MATERIALS AND METHODS}

\section{Essential oils}

The essential oils extracted from the leaves of $O$. vulgare and O. majorana were obtained from Ferquima Ind. e Com. Ltda. (Vargem Grande Paulista, São Paulo, Brazil) and their quality parameters (appearance, color, purity, odor, density $-20^{\circ} \mathrm{C}$, refraction index $-20^{\circ} \mathrm{C}$ ) were described in an accompanying technical report. The essential oils were tested in the range of $320-0.03 \mu \mathrm{L} /$ $\mathrm{mL}$. Solutions of essential oils were prepared in Sabouraud Broth (SB) using bacteriological agar $(0.15 \mathrm{~g} / 100 \mathrm{~mL})$ as the stabilizing agent according to Bennis et al. (2004).

\section{Fungi}

Candida albicans ATCC-7645, C. tropicalis LM14, C. krusei LM-09, Cryptococcus neoformans FGF-5, Aspergillus flavus LM-02, A. fumigatus IPP-21, T. rubrum ATCC-28184, T. mentagrophytes LM-64, Microsporum gypseum ATCC 184, M. canis LM-36 and Cladosporium herbarium ATCC 26362 were used as test microorganisms. These strains were supplied by the Laboratory of Mycology, Department of Pharmaceutical Sciences, Federal University of Paraíba, João Pessoa, Brazil. Stock cultures were kept on Sabouraud Agar (SA) slants under refrigeration.

For antifungal assays, the fungi were cultivated on SA slants for $24-48$ h at $37^{\circ} \mathrm{C}$ and for $10-14$ days at 28 ${ }^{\circ} \mathrm{C}$, for yeasts and moulds, respectively. Suspensions of the microorganisms were prepared in sterile saline solution $(0.9 \mathrm{~g} / 100 \mathrm{~mL})$ with added Tween $80(1 \mathrm{~g} / 100 \mathrm{~mL})$. Suspensions were adjusted to contain approximately $10^{6}$ count forming unit per $\mathrm{mL}(\mathrm{cfu} / \mathrm{mL})$ and $10^{6}$ spores per $\mathrm{mL}$ (spores $/ \mathrm{mL}$ ) for yeasts and moulds, respectively, according to Cleeland and Squires (1991) and Carmo et al. (2008).

\section{Synthetic antifungals}

The sensitivity of the fungal strains to the standard antifungals amphotericin B, nistatin, fluconazole, 5-fluorocytosine and ketoconazole (Table I) was assessed by the solid medium diffusion procedure using filter paper discs (CECON Ltda, São Paulo, Brazil).

\section{Minimal Inhibitory Concentration (MIC)}

A solid medium diffusion technique employing wells in dishes was used to determine the MIC of the essential oils. A $1 \mathrm{~mL}$ quantity of the fungal suspension was uniformly spread in sterile SA Petri dishes. After the inoculum

TABLE I - Synthetic compounds applied in the antifungal assays

\begin{tabular}{lccc}
\hline Antifungal & $\begin{array}{c}\text { Assayed } \\
\text { Concentration }\end{array}$ & $\begin{array}{c}\text { Diameter of } \\
\text { inhibition zones }\end{array}$ & Interpretation* \\
\hline 5-Fluorocytosine & $1 \mathrm{mcg}$ & $>20$ & $\begin{array}{c}\text { Sensitive } \\
\text { Intermediary } \\
\text { (5- FC1) }\end{array}$ \\
Resistant \\
Amphotericin B & $100 \mathrm{mcg}$ & $20-10$ & $\begin{array}{c}\text { Sensitive } \\
\text { (AB) }\end{array}$ \\
& & $>10$ & Intermediary or \\
Nistatin & 100 U.I. & $\leq 10$ & Resistant \\
(NI) & & & Sensitive \\
Fluconazole & $25 \mathrm{mcg}$ & $>10$ & Resistant \\
(FLU) & & $\leq 10$ & Sensitive \\
& & $>19$ & Intermediary \\
Ketoconazole & $50 \mathrm{mcg}$ & $19-14$ & Resistant \\
(KET) & & $\leq 14$ & Sensitive \\
& & $>20$ & Intermediary \\
5-Fluorocytosine * & $1 \mathrm{mcg}$ & $20-10$ & Resistant \\
(5-FC1) & & $\leq 10$ & Sensitive \\
& & $>10$ & Intermediary or \\
\hline
\end{tabular}

*According to NCCLS (1997); ** only for A. fumigatus 
absorption by SA, wells were made using sterile glass stems (diameter $6 \mathrm{~mm}$ ) into which $50 \mu \mathrm{L}$ volumes of the essential oils solutions were added. Subsequently, the system was incubated for $48 \mathrm{~h}$ at $37^{\circ} \mathrm{C}$ and for 7 days at $28^{\circ} \mathrm{C}$ for yeasts and moulds, respectively. At the end of the incubation period, the inhibition zones were measured. The lowest concentration of the essential oils able to develop inhibition zones with a diameter greater than or equal to $10 \mathrm{~mm}$ was considered the MIC (Hadacek, Greger, 2000).

\section{Measure of fungal viability}

The influence of $O$. vulgare essential oil $(80 \mu \mathrm{L} / \mathrm{mL})$, O. majorana essential oil $(160 \mu \mathrm{L} / \mathrm{mL})$ and ketoconazole $(50 \mu \mathrm{L} / \mathrm{mL})$ on the viability of C. albicans ATCC-7645 was determined using the viable cell count procedure. For this, $5 \mathrm{~mL}$ volumes of sterile double strength $\mathrm{SB}$ were inoculated with $1 \mathrm{~mL}$ of the yeast inocula. Subsequently, $4 \mathrm{~mL}$ of the antifungals solutions were added to the system and followed by shaking using a Vortex for $30 \mathrm{~s}$. The system was incubated at $28^{\circ} \mathrm{C}$. At different time intervals $(0,1,2,4,6,8,10,12$ and $24 \mathrm{~h})$ post-incubation, $1 \mathrm{~mL}$ of the suspension was serially diluted in sterile peptone buffer and spread on sterile SA Petri dishes, followed by incubation for $48 \mathrm{~h}$ at $28^{\circ} \mathrm{C}$. Control flasks without essential oil or ketoconazole were tested in the same manner. After the incubation period, the mean number of $\mathrm{cfu} / \mathrm{mL}$ was counted (Souza et al., 2007). The detection limit for viable cell count was $2 \log \mathrm{cfu} / \mathrm{mL}$.

\section{Measurement of radial mycelial growth}

Inhibition by $O$. vulgare essential oil $(80 \mu \mathrm{L} / \mathrm{mL})$ and ketoconakole $(50 \mu \mathrm{g} / \mathrm{mL})$ of the radial mycelial growth of T. rubrum and M. canis was assessed using the poisoned substrate technique (dilution in solid medium). For this, a $2 \mathrm{~mm}$ plug taken from a 10 day-old mould culture grown on SA slants at $28^{\circ} \mathrm{C}$ was placed in the center of a sterile SA Petri dish along with antifungals added at a suitable concentration and incubated at $28{ }^{\circ} \mathrm{C}$. At different intervals $(0,2,4,6,8,10,12$ and 14 days) after incubation, the radial mycelial growth was measured $(\mathrm{mm})$ using calipers. Control flasks without essential oil or ketoconazole were tested in the same manner (Daferera et al., 2003).

\section{Sorbitol assay}

The sorbitol assay was carried out in an attempt to unveil a possible mechanism involved in the establishment of the antifungal property of the tested essential oils. A. flavus LM-02 was included in this assay as a test strain. For this, $1 \mathrm{~mL}$ of the fungal suspension was added to $4 \mathrm{~mL}$ of the essential oil solutions at the suitable concentrations. Subsequently, $5 \mathrm{~mL}$ of double strength SB with the addition of the osmotic protectant sorbitol (final concentration $0.8 \mathrm{M}$ ) was introduced to the system followed by shaking for $30 \mathrm{~s}$ using a Vortex. The system was statically incubated for 7 days at $28^{\circ} \mathrm{C}$. MIC was defined as the lowest concentration of the essential oil required to completely prevent visible fungal growth. Control flasks of SB without sorbitol (standard media) were tested in the same manner. Based on the ability of sorbitol to act as an osmotic protector of fungi cell wall, the higher MIC values observed in the media with added sorbitol compared to the standard media implicated the cell wall as one of the possible cell targets of the essential oils (Frost et al., 1995).

\section{Fungal morphogenesis study}

In order to evaluate morphological alterations caused by the essential oil from $O$. vulgare in $A$. flavus LM-02, a sample of mycelium was taken from the periphery of a 10 -day-old fungal colony grown on $\mathrm{SA}$ at $28^{\circ} \mathrm{C}$ containing the essential oil $(80 \mu \mathrm{L} / \mathrm{mL})$. The samples were fixed in lacto-phenol-cotton blue stain and observed under the microscope at $400 \mathrm{x}$ to examine morphological abnormalities. The control assay without essential oil was tested in the same manner (Sharma, Tripathi, 2008).

All antifungal assays were carried out in triplicate and the results were expressed as an average of the two parallel assays.

\section{RESULT AND DISCUSSION}

Results of the MIC values of $O$. vulgare and $O . m a-$ jorana essential oil against several potentially pathogenic fungi are shown in Table II. The findings reveal that both of the essential oils provided inhibition of most of the fungi strains tested. $O$. vulgare essential oil showed an MIC value of $80 \mu \mathrm{L} / \mathrm{mL}$, while $O$. majorana had an MIC value of $160 \mu \mathrm{L} / \mathrm{mL}$. Three tested strains were resistant to all assayed concentrations of $O$. vulgare essential oil, versus five for O. majorana essential oil. C. krusei was the only strain resistant to both essential oils. These results suggested a wider spectrum of antifungal activity for $O$. vulgare essential oil. Likewise, Oliveira et al. (2009) found lower MIC values for O. majorana essential oil against Staphylococcus aureus and Enterobacter spp. in comparison to $O$. vulgare essential oil.

Carmo et al. (2008) found MIC values of O. vulgare essential oil ranging from 20 to $80 \mu \mathrm{L} / \mathrm{mL}$ against the Aspergilli species. For A. flavus and A. fumigatus these 
TABLE II - MIC of the essential oil from $O$. vulgare L. and $O$. majorana $\mathrm{L}$. against some potentially pathogenic fungi*

\begin{tabular}{lcc}
\hline Microorganisms & \multicolumn{2}{c}{ Essential oils $(\mu \mathrm{L} / \mathrm{mL})$} \\
& O. vulgare $\mathrm{L}$. & O. majorana $\mathrm{L}$. \\
\hline C. albicans ATCC 7645 & 80 & 160 \\
C. tropicalis LM-14 & 80 & 160 \\
C. krusei LM-09 & $\mathrm{R}$ & $\mathrm{R}$ \\
C. neoformans FGF-5 & 80 & 160 \\
T. rubrum ATCC 28184 & 80 & $\mathrm{R}$ \\
T. mentagrophytes LM-64 & $\mathrm{R}$ & 160 \\
M. gypseum ATCC 184 & $\mathrm{R}$ & 160 \\
M. canis LM-36 & 80 & $\mathrm{R}$ \\
C. herbarium ATCC 26362 & 80 & $\mathrm{R}$ \\
A. flavus LM-02 & 80 & 160 \\
A. fumigatus IPP-21 & 80 & $\mathrm{R}$ \\
\hline
\end{tabular}

* results expressed in diameter $(\mathrm{mm})$ of inhibition zones; $\mathrm{R}$ : resistant to all assayed concentrations

authors found MIC of 20 and $40 \mu \mathrm{L} / \mathrm{mL}$, respectively. Souza et al. (2007) detected MIC values for O. vulgare oil of between 10 and $20 \mu \mathrm{L} / \mathrm{mL}$ against Candida species. Bussata et al. (2008) found average MIC values for O. majorana essential oil of 1.1 and $1.6 \mathrm{mg} / \mathrm{mL}$ against positive and negative Gram bacteria, respectively.

Earlier studies of in vitro antimicrobial activity reported in the literature have found terpinen-4-ol as the main component of $O$. majorana essential oil (Ezzeddine et al., 2001; Vági et al., 2005; Busatta et al., 2008). Main compounds of $O$. vulgare essential oil have been identified as carvacrol and thymol (Souza et al., 2008; Barros et al., 2009). Other compounds such as $\alpha$-pinene, $p$-cymene, $\gamma$-terpinene, caryophyllene oxide, germacrene, linalool and trans-sabinene have been found in both oils at low percentages.

The effect of the MIC of O. vulgare and O. majorana essential oil on the viability of C. albicans ATCC-7645 is shown in Figure 1. Both essential oils produced a sharp drop in fungal count throughout the evaluated intervals establishing a cidal effect after $4 \mathrm{~h}$ of exposure. From $4 \mathrm{~h}$ onwards, no recovery in cell count was noted. A compound was considered as having a strong fungicidal effect when able to cause a decrease of $99.9 \%$ (3 log cycles) of the initial inoculum (Espinell Ingroff, 1992). No significant difference $(p>0.05)$ was found among the yeast counts for the broth with added essential oils and the standard antifungal ketoconazole. Ketoconazole was included in the growth kinetic assay because no tested fungi presented resistance to it in solid medium diffusion assay. The other antifungal showed a weak capacity in inhibiting at least one tested strain (Table III).

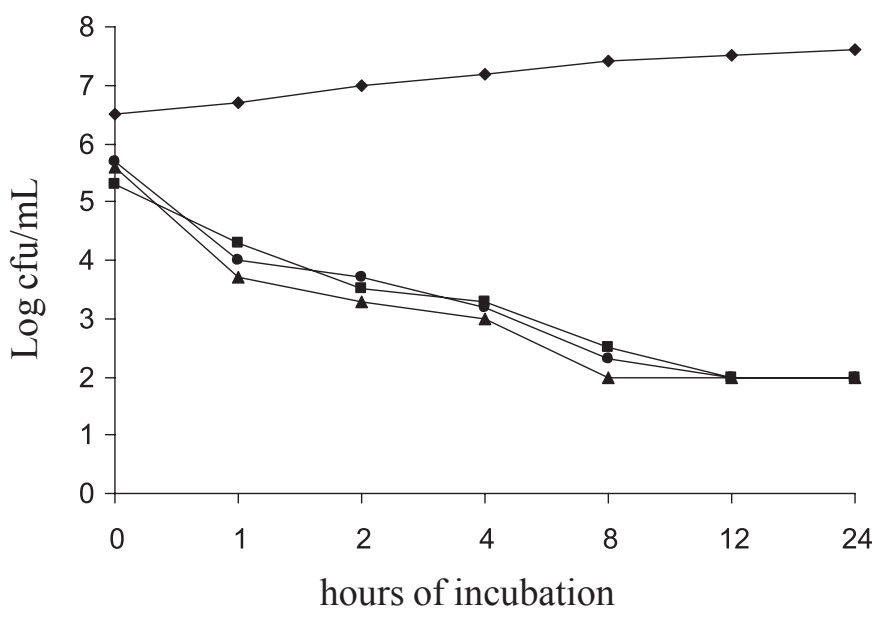

FIGURE 1 - Survivor curves for C. albicans ATCC 7645 in Sabouraud broth as a function of the antifungal compound: $(\bullet)$ : control $(0 \mu \mathrm{L} / \mathrm{mL}) ;(\boldsymbol{\Delta})$ : $O$. vulgare essential oil $(80 \mu \mathrm{L} / \mathrm{mL})$; (O): O. majorana essential oil $(160 \mu \mathrm{L} / \mathrm{mL}$; ( $)$ : ketoconazole $(50 \mu \mathrm{g} / \mathrm{mL})$.

TABLE III - Sensitivity of potentially pathogenic fungi to standard antifungals

\begin{tabular}{lccccc}
\hline Fungi & \multicolumn{5}{c}{ Standard antifungals } \\
& AB & NI & 5FC & FLU & KET \\
\hline C. albicans ATCC 7645 & $\mathrm{S}$ & $\mathrm{S}$ & $\mathrm{R}$ & $\mathrm{S}$ & $\mathrm{S}$ \\
C. tropicalis LM-14 & $\mathrm{R}$ & $\mathrm{S}$ & $\mathrm{I}$ & $\mathrm{I}$ & $\mathrm{S}$ \\
C. krusei LM-09 & $\mathrm{R}$ & $\mathrm{S}$ & $\mathrm{I}$ & $\mathrm{R}$ & $\mathrm{S}$ \\
C. neoformans FGF-5 & $\mathrm{S}$ & $\mathrm{S}$ & $\mathrm{R}$ & $\mathrm{R}$ & $\mathrm{S}$ \\
T. rubrum ATCC 28184 & $\mathrm{R}$ & $\mathrm{S}$ & $\mathrm{R}$ & $\mathrm{R}$ & $\mathrm{S}$ \\
T. mentagrophytes LM-64 & $\mathrm{R}$ & $\mathrm{S}$ & $\mathrm{R}$ & $\mathrm{R}$ & $\mathrm{S}$ \\
M. gypseum ATCC 184 & $\mathrm{R}$ & $\mathrm{R}$ & $\mathrm{R}$ & $\mathrm{R}$ & $\mathrm{I}$ \\
M. canis LM-02 & $\mathrm{R}$ & $\mathrm{S}$ & $\mathrm{R}$ & $\mathrm{R}$ & $\mathrm{S}$ \\
C. herbarium ATCC 26362 & $\mathrm{R}$ & $\mathrm{S}$ & $\mathrm{R}$ & $\mathrm{R}$ & $\mathrm{S}$ \\
A. flavus LM-02 & $\mathrm{R}$ & $\mathrm{S}$ & $\mathrm{R}$ & $\mathrm{R}$ & $\mathrm{I}$ \\
A. fumigatus IPP-21 & $\mathrm{R}$ & $\mathrm{S}$ & $\mathrm{R}$ & $\mathrm{R}$ & $\mathrm{I}$ \\
\hline
\end{tabular}

* results expressed in diameter (mm) of inhibition zones; R: resistant; S: Sensitive

The effect of $O$. vulgare essential oil on the radial mycelial growth of T. rubrum ATCC-28184 and M. canis LM-36 in solid medium is shown in Figure 2 and 3, respectively. The essential oil at $80 \mu \mathrm{L} / \mathrm{mL}$ exhibited a fumigant effect against both fungi. $O$. vulgare provided a $100 \%$ lethal effect against both fungi after 2 days. $T$. rubrum and $M$. canis presented a slight increase in radial growth when exposed to $50 \mu \mathrm{g} / \mathrm{mL}$ of ketoconazole. However, the mould growth was always lower than that noted in the control assay. The control assay showed 


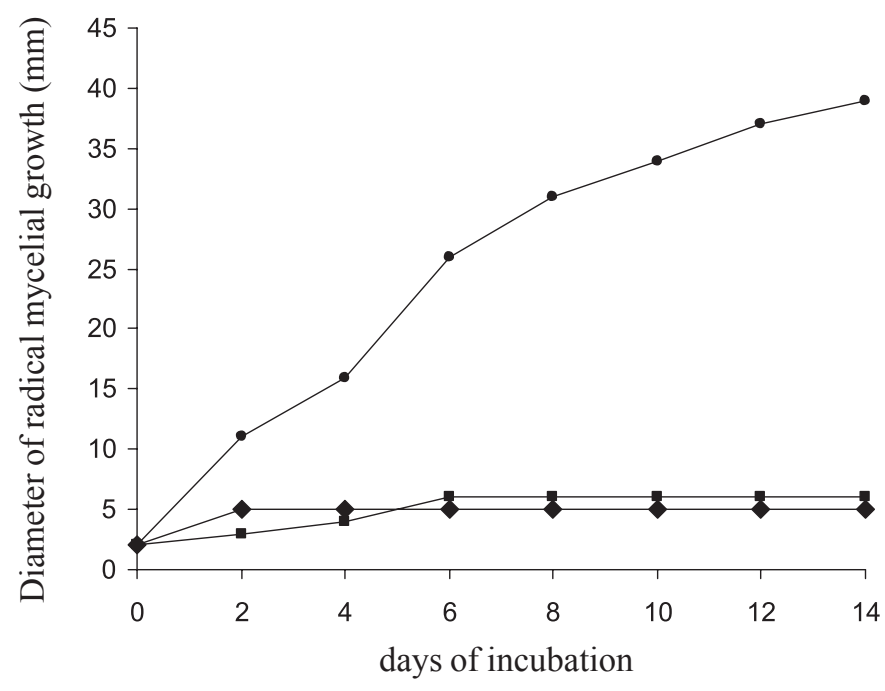

FIGURE 2 - Radial mycelia growth for T. rubrum ATCC 28184 as a function of the antifungal compound: $(\bullet)$ : control $(0 \mu \mathrm{L} /$ $\mathrm{mL})$; (४): O. vulgare essential oil $(80 \mu \mathrm{L} / \mathrm{mL}) ;(\boldsymbol{\square})$ : ketoconazole $(50 \mu \mathrm{g} / \mathrm{mL})$.

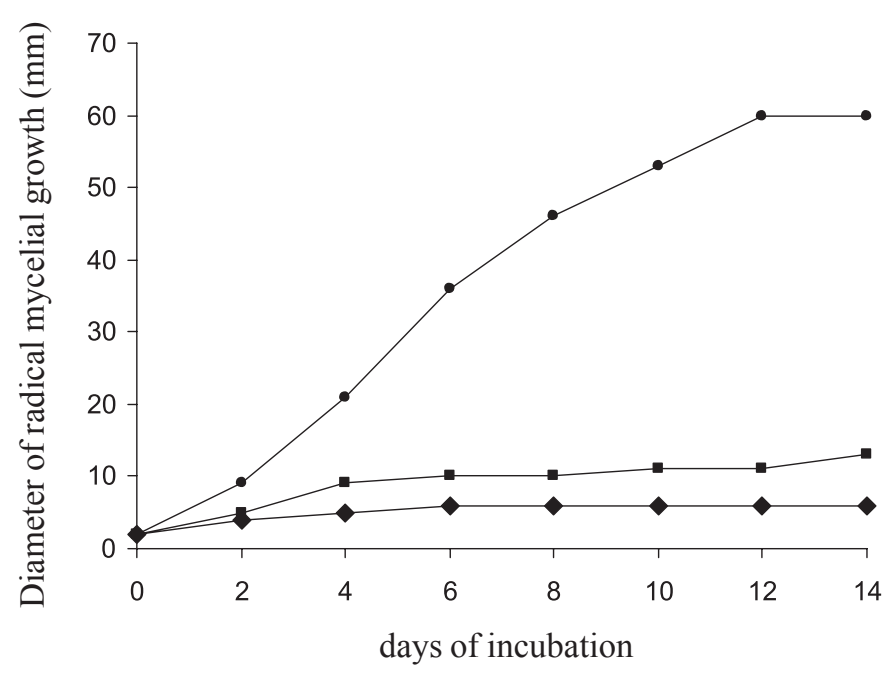

FIGURE 3 - Radial mycelia growth for $M$. canis LM-36 as a function of the antifungal compound: (-): control $(0 \mu \mathrm{L} / \mathrm{mL})$; $(\diamond)$ : O. vulgare essential oil $(80 \mu \mathrm{L} / \mathrm{mL}) ;(\boldsymbol{\square})$ : ketoconazole $(50 \mu \mathrm{g} / \mathrm{mL})$.

a steady rate of mycelia growth for all the time points evaluated.

Few studies have focused on the effect of essential oils on the radial mycelial growth of pathogenic fungi. Carmo et al. (2008) found that the essential oil from Cinnamomum zeylanicum $(20-80 \mu \mathrm{L} / \mathrm{mL})$ caused inhibition of the mycelial growth of $A$. niger for 14 days.

The MIC of the essential oil from $O$. vulgare and $O$. majorana against $A$. flavus LM-02 by macrodilution assay in the presence and absence of sorbitol in the growth media are shown in Table IV. The MIC values found for + and
- sorbitol treatments differed. The MIC without sorbitol was 0.125 and $4 \mu \mathrm{L} / \mathrm{mL}$ for $O$. vulgare and $O$. majorana, respectively, whereas for the assay with sorbitol values were 1.0 and 16 . According to these findings, the assayed fungus strain protected by sorbitol grew in the presence of up to 0.06 and $8 \mu \mathrm{L} / \mathrm{mL}$ of $O$. vulgare and $O$. majorana essential oil (regarding the use of serially diluted solutions), respectively. Since sorbitol is known as an osmo-stabilizer protecting the cell wall from lysis caused by antifungal agents, these findings suggests some specificity of these essential oils for targeting cell wall in the mould cell.

TABLE IV - MIC of the essential oil from $O$. vulgare L. and $O$. majorana L. against $A$. flavus LM-02 in presence and absence of sorbitol

\begin{tabular}{lcc}
\hline Essential oil & \multicolumn{2}{c}{$\mathrm{MIC}(\mu \mathrm{L} / \mathrm{mL})$} \\
& - sorbitol & + sorbitol \\
\hline O. vulgare L. & 0.125 & 4.0 \\
O. majorana $\mathrm{L}$. & 0.06 & 8.0 \\
\hline
\end{tabular}

(-): without sorbitol; (+): with sorbitol

According to Frost et al. (1995) the protection of fungal growth with sorbitol is not limited to $\beta-(1,3)$ glucan synthesis inhibitors but can also be applied to inhibitors of synthesis of other cell wall polymers, and the mechanisms controlling cell wall synthesis. These authors also stated that the sorbitol protection assay is known as a broad spectrum screen for finding not only compounds that directly interfere in cell wall synthesis and assembly but also regulatory mechanisms involved in this process.

Macrodilution in broth assay was used for detecting the MIC in sorbitol assay. The MIC values for both assayed essential oils found in sorbitol assay were lower than those seen in solid medium diffusion assay. This disparity in results could largely be related to the variation of the neat essential oil on the disc or in the well, of the disc or well size, agar composition or the volatility of the essential oil in an open air system when using the solid medium diffusion technique (Pattnail et al., 1996; Viljoen et al., 2003). However, it is well established that the antifungal property of different essential oils ranges from a narrow to wide spectrum depending on the assayed essential oil, its concentration and fungal target (Burt, Reinders, 2003). Moreover, the oil volatility during the incubation period could possibly be responsible for higher MIC values when using the solid medium diffusion procedure in comparison to dilution assays (Sahin et al., 2004; Duarte et al., 2005). 
Cells treated with compounds that interfere with cell wall biosynthesis often have distinct morphological characteristics. The changes in morphology could suggest the possible target or mode of action of the inhibitor. Observations of $A$. flavus LM-02 under the light microscope at $400 \mathrm{x}$ magnification after exposure to $80 \mu \mathrm{L} / \mathrm{mL}$ of $O$. vulgare essential oil showed some morphological abnormalities (Figure 4).

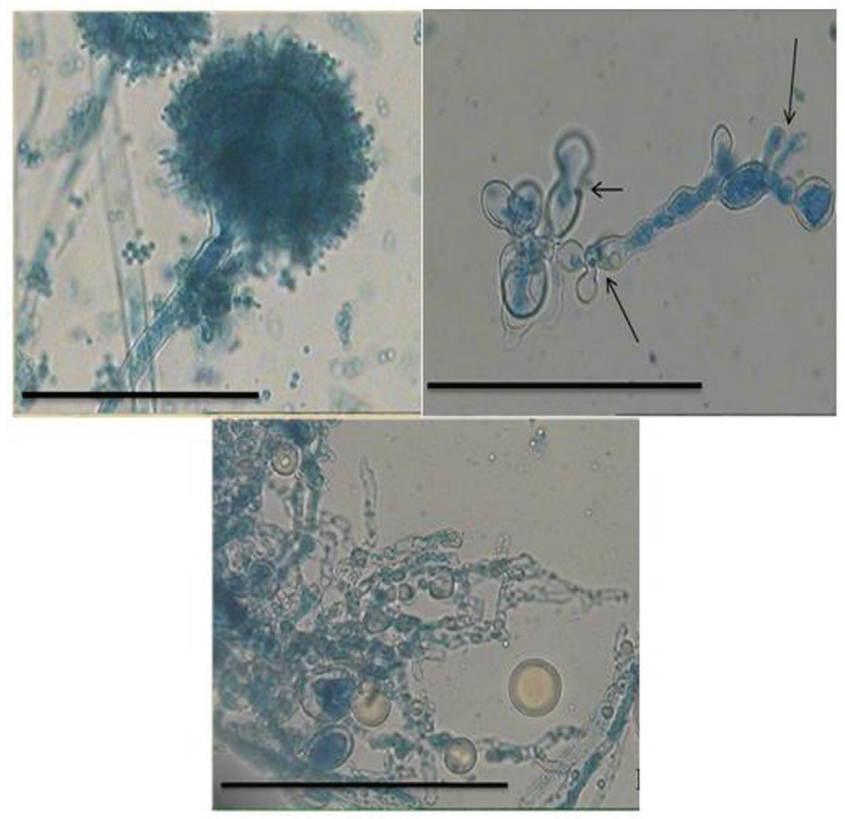

FIGURE 4 - Light microphotographs of $A$. flavus LM-02 mycelium growing on AS with or without $O$. vulgare $(80 \mu \mathrm{L} /$ $\mathrm{mL}$ ) essential oil during 7 days of incubation at $25-28^{\circ} \mathrm{C}$. (a) Control conidial head of $A$. flavus, large and radiated, development of vesicle on conidiophore, conidia clearly visible, Bar $100 \mu \mathrm{m}$. (b) (b-c) Hyphae modification induced by $O$. vulgare essential oil showing anomalous structure with bud-like formation and loss of pigmentation; clear leakage of cytoplasm content and destruction of cell structure evidenced by disrupted hyphae integrity, Bar $100 \mu \mathrm{m}$.

Microscopic examination of the control mycelium (untreated cell) of A. flavus LM-02 revealed regular cell structure with homogenous cytoplasm, clearly visible conidia and profuse conidiation on a large and radiated conidial head. The mycelia cultivated in the medium with added essential oil appeared to present morphological changes with distortion of hyphaes. The morphological changes found were loss of cytoplasm content (empty hyphae), loss of pigmentation, distorted development of hyphae and empty hyphae. The hyphae become distorted with swelling in their structure and budded apical tips. In addition, the oil caused a clear absence of conidiation.
De Billeberk et al. (2001) and Rasooli and Abyaneh (2004) stated that these kinds of morphological changes in moulds caused by exposure to essential oils suggest that the mode of antifungal activity could include an attack on the cell wall and retraction of the cytoplasm in the hyphae ultimately resulting in death of mycelium. Moreover, Carmo et al. (2008) reported that these changes could also be related to the interference of the essential oil components in enzymatic reactions of cell wall synthesis affecting the fungal growth and morphogenesis.

These results are in agreement with the findings of the sorbitol assay, reinforcing the theory of the cell wall as a target for the antifungal activity of the assayed essential oil. Frost et al. (1995) stated that combining the analysis of growth with sorbitol assay and the study of morphology characteristics of cells (Sorbitol Protection and Analysis of Morphology - SPAM) could lead to a suitable procedure for detection of cell wall-acting antifungal agents.

Velluti et al. (2003) suggested that antimicrobial activity of essential oil depends on the chemical structure of its components. Phenolic compounds known to be constituents of $O$. vulgare and $O$. majorana essential oil have antimicrobial properties attributable to the presence of an aromatic group known to be reactive and to form hydrogen bonds with active sites of target enzymes (Dimitriević et al., 2007; Souza et al., 2007). However, it has also been suggested that the effectiveness of complete essential oils is higher than the activity of each separate compound (Milos et al., 2000).

In conclusion, our results indicate that essential oils from Origanum species could have a practical and promising use in the inhibition of fungal growth. More specifically, the broad inhibition of fungal growth by the essential oils from $O$. vulgare and $O$. majorana justifies their possible rational use as an alternative antifungal compound to control the growth of pathogen fungi and the occurrence of mycoses.

\section{REFERENCES}

AL-FATIMI, M.; WURSTER, M.; SCHRÖDER, G.; LINDEQUIST, U. Antioxidant, antimicrobial and cytotoxic activities of selected medicinal plants from Yemen. $J$. Ethnopharmacol., v.111, p.657-666, 2007.

ALIGIANS, N.; KALPOUTZAKIS, E.; MITAKU, S.; CHINOU, I.B. Composition and antimicrobial activity of the essential oil of two Origanum species. J. Agric. Food Chem., v.49, p.4168-4170, 2001. 
BARROS, J.C.; CONCEIÇÃO, M.L.; GOMES NETO, N.J.; COSTA, A.C.V.; SIQUEIRA JÚNIOR, J.P.; BASÍLIO JÚNIOR, I.D.; SOUZA, E.L. Interference of Origanum vulgare L. essential oil on the growth and some physiological characteristics of Staphylococcus aureus strains isolated from foods. Lebens. Wiss.-und Technol., v.42, p.1139-1143, 2009.

BASER, K.H.C. Essential oils of Anatolian Labiatae: a profile. Acta Horticult., v.333, p.217-238, 1993.

BASER, K.H.C. Essential oils of Labiatae from Turkey: recent results. Lamiales Newsletter, v.3, p.6-11, 1994.

BAYDAR, H.; SAGDIÇ, O.; OZKAN, G.; KARADOGAN, T. Antibacterial activity and composition of essential oils from Origanum, Thymbra and Sartureja species with commercial importance in Turkey. Food Cont., v.15, p.169-172, 2004.

BENNIS, S.; CHAMI, F.; CHAMI, T.; BOUCHIKHI, T.; REMMAL, A. Surface alteration of Saccharomyces cereviseae induced by thymol and eugenol. Let. Appl. Microbiol., v.38, p.454-458, 2004.

BURT, S.A.; REINDERS, R.D. Antibacterial activity of selected plant essential oils against Escherichia coliO157:H7. Let. Appl. Microbiol., v.26, p.162-167, 2003.

BUSSATTA, C.; VIDAL, R.S.; POPIOLSKI, A.S.; MOSSI, A.J.; DARIVA, C.; RODRIGUES, M.R.A.; CORAZZA, F.C.; CORAZZA, M.L.; VLADIMIR OLIVEIRA, J.; CANSIAN, R.L. Application of Origanum majorana L. essential oil as an antimicrobial agent in sausage. Food Microbiol., v.25, p.207-221, 2008.

CARMO, E.S.; LIMA, E.O.; SOUZA, E.O. the potential of Origanum vulgare 1. (Lamiaceae) essential oil in inhibiting the growth of some food-related Aspergillus species. Braz. J. Microbiol., v.39, p.362-367, 2008.

CLEELAND, R.; SQUIRES, E. Evaluation of new antimicrobials vitro and experimental animal infection. In: LORIAN, V. (Ed.) Antibiotics in laboratory medicine. 3.ed. Baltimore: Williams and Wilkiam, 1991. p.739-787.

COWAN, A. M. Plant products as antimicrobial agents. Clin. Microbiol. Rev., v.12, p.564-582, 1999.
CRISTIANI, M.; D'ARRIGO, M.; MANDALARI, G.; CASTELLI, F.; SARPIETRO, M.G.; MICIELI, D. Interaction of four monoterpenes contained in essential oils with model membranes: implications for their antibacterial activity. J. Agric. Food Chem., v.55, p.6300-6308, 2007.

DAFERERA, D.J.; ZIOGAS, B.N.; POLISSIOU, M.G. The effectiveness of plant essential oils on the growth of Botrytis cinerea, Fusarium sp. and Clavibacter michiganensis subsp. michiganensis. Crop Prot., v.22, p.39-44, 2003.

DE BILLERBERK, V.G.; ROQUES, C.G.; BESSIERE, J.M.; FONVIEILLE, J.L.; DARGENT, R. Effects of Cymbopogon nardus (L.) W. Watson essential oil on the growth and morphogenesis of Aspergillus niger. Can. J. Microbiol., v.47, p.9-17, 2001.

DIMITRIJEVIĆ, S.I.; MIHAJLOVSKI, K.R.; ANTONOVIĆ, D.G.; MILANOVIĆ-STEVANOVIĆ, M.R.; MIJIN, D.Z. A study of the synergistic antilisterial effects of a sub-lethal dose of lactic acid and essential oils from Thymus vulgaris L., Rosmarinus officinalis L. and Origanum vulgare L. Food Chem., v.104, p.774-782, 2007.

DORMAN, H.J.D.; DEANS, S.G. Antimicrobial agents from plants: antibacterial activity of plant volatile oils. J. Appl. Bacteriol., v.88, p.308-316, 2000.

DUARTE, M.C.T.; FIGUEIRA, G.M.; SARTORATTO, A.; REHDER, V.L.G.; DELARMELINA, C. Anti-Candida activity of Brazilian medicinal plants. J. Ethnopharm., v.97, p.305-311, 2005.

DUBEY,A.; PATWARDHAN, R.V.; SAMPTH, S.; SANTOSHI, V.; KOLLURI, S.; NANDA, A. Intracranial fungal granuloma: analysis of 40 patients and review of the literature. Surg. Neurol., v.63, p.254-260, 2006.

ESPINELL INFROFF, A. Collaborative comparison of broth macrodilution and microdilution antifungal susceptibility tests. J. Clin. Microbiol., v.30, p.3128-3145, 1992.

EZZEDDINE, N.B.; ABDELKEFI, M.M.; BEN-AISSA, R.; CHAABOUNI, M.M. Antibacterial screening of Origanum majorana L. oil from Tunisia. J. Essent. Oil Res., v.13, p.295-297, 2001.

FROST, D.J.; BRANDT, K.D.; CUGIER, D.; GOLDMAN, R. A whole-cell Candida albicans assay for the detection towards fungal cell wall synthesis and assembly. J. Antibiotic, v.48, p.306-310, 1995. 
HADACEK, F.; GREGER, H. Testing of antifungal natural products: methodologies, comparability of results and essay choice. Phytochem. Anal., v. 11, p.137-147, 2000.

KIRSCH, D.; LAI, M.H. A modified screen for the detection of cell wall-acting antifungal compounds. J. Antibiotic, v.39, p.1620-1622, 1986.

KNOWLES, J. R.; ROLLER, S.; MURRAY, D. B.; NAIDU, A. S. Antimicrobial action of carvacrol at different stages of dual species biofilm development by Staphylococcus aureus and Salmonella enterica Serovar Typhimurium. Appl. Environm. Microbiol., v.71, p.797-803, 2005.

KOROISHI, A.K.; FOSS, S.R.; CORTEZ, D.A.G.; UEDANAKAMURA, T.; NAKAMURA, C.V.; DIAS FILHO, B.P. In vitro antifungal activity of extracts and neolignans from Piper regnellii against dermatophytes. J. Ethnopharmacol., v.117, p.270-277, 2008.

LIMA, I.O.; OLIVEIRA, R.A.G.; LIMA, E.O.; FARIAS, N.M.P.; SOUZA, E.L. Atividade antifúngica de óleos essenciais sobre espécies de Candida. Rev. Bras. Farmacogn. v.16, p.197-201, 2006.

MARINO, M.; BERSANI, C.; COMI, G. Impedance measurements to study the antimicrobial activity of essential oils from Lamiaceae and Compositae. Int. J. Food Microbiol., v.67, p.187-195, 2001.

MILOS, M.; MASTELIC, J.; JERKOVIC, L. Chemical composition and oxidant effect of glicosidically bound volatile compounds from Oregano (Origanum vulgare L. spp. hirtum). Food Chem., v.71, p.79-83, 2000.

MOELLERING JR., R.C.; GRAYBILL, J.R.; MCGOWAN JR., J.E.; COREY, L. Antimicrobial resistance prevention initiative-an update: Proceedings of an expert panel on resistance. Am. J. Infec. Cont., v.35, p.1-23, 2007.

\section{NATIONAL COMMITTEE FOR CLINICAL LABORATORY} STANDARDS - NCCLS Performance standards of antimicrobial disk susceptibility test. Atlanta, 1997. 115 p.

NOVAK, J.; CHRISTINA, B.; LANGBEHN, B.; PARK, F.; SKOULA, M.; GORSIOU, Y.; FRANZ, C.M. Ratios of cis- and trans- sabinene hydrate in Origanum marjorana L. and Origanum midrophyllum (Bentham). Biochem. System. Ecol., v.28, p.697-704, 2000.
OLIVEIRA, J.L.T.; DINIZ, M.F.F.M.; LIMA, E.O.; SOUZA, E.L.; TRAJANO, V.N.; SANTOS, B.H.C. Effectiveness of Origanum vulgare L. and Origanum majorana L. essential oils in inhibiting the growth of bacterial strains isolated from the patients with conjunctivitis. Braz. Arch. Biol. Technol., v.52, p.45-50, 2009.

PATTNAIL, S.; SUBRAMANYAN, V.R.; KOLE, C. Antibacterial antifungal activity of ten essential oils in vitro. Microbios, v.86, p.121-126, 1996.

RASOOLI, I.; ABYANEH, M.R. Inhibition effects of Thyme oils on growth and aflatoxin production by Aspergillus parasiticus. Food Cont., v.15, p.479-483, 2004.

REISS, R.; HEARN, V.M.; POULAIN, D.; SHEPHERD, M.G. Structure and function of the fungal cell wall. J. Med. Vet. Mycology, v.30, p.143-156, 1992.

SAHIN, F.; GULLUCE, M.; DAFERERA, D.; SOKMEN, A.; POLISSIOU, M.; AGAR, G.; OZER, H. Biological activities of the essential oils and methanol extract of Origanum vulgare ssp. vulgare in the Eastern Anatolia region of Turkey. Food Cont., v.15, p.549-557, 2004.

SHARMA, N.; TRIPATHI, A. Effects of Citrus sinensis (L.) Osbeck epicarp essential oil on growth and morphogenesis of Aspergillus niger (L.) Van Tieghem. Microbiol. Res., v.163, p.337-344, 2008.

SIVROPOULOU, A.; PAPANIKOLAU, E.; NICOLAU, C.; KOKKINI, S.; LANARAS, T.; ARSENAKIS, M. Antimicrobial and citotoxic activities of Origanum vulgare essential oil. J. Agric. Food Chem., v.44, p.1202-1205, 1996.

SOUZA, E.L.; STAMFORD, T.L.; LIMA, E.O.; BARBOSA FILHO, J.M.; MARQUES. M.O.M. Interference of heating on the antimicrobial activity and chemical composition of Origanum vulgare L. (Lamiaceae) essential oil. Cien. Tecnol. Alim., v.28, p.1-5, 2008.

SOUZA, E.L.; STAMFORD, T.L.M.; LIMA, E.O.; TRAJANO, V.N. Effectiveness of Origanum vulgare L. essential to inhibit the growth of food spoiling yeasts. Food Cont., v.18, p.409-413, 2007.

VÁGI, E.; SIMÁNDI, B.; SUHAJDA, Á.; HÉTHELYI, E. Essential oil composition and antimicrobial activity of Origanum majorana L. extracts obtained with ethyl alcohol and supercritical carbon dioxide. Food Res. Int., v.38, p.5157, 2005. 
VARONA, R.; PÉREZ, P.; DURÁN, A. Effect of papulacandin $\mathrm{B}$ on $\beta$-glucan synthesis in Schizosaccharomyces pombe. FEMS Microbiol. Let., v.20, p.243-247, 1983.

VELLUTI, A.; SANCHIS, V.; RAMOS, A.J.; MARÍN, J.E.S. Inhibitory effect of cinnamon, clove, lemongrass, oregano and palmarose essential oils on growth and fumonisin production by Fusarium proliferatum in maize grains. Int. J. Food Microbiol., v.89, p.145-154, 2003.

VILJOEN, A.; VAN VUUREN, S.; ERNST, E.; KLEPSER, M.; DEMIRCI, B.; BASER, H. Osmitopsis astericoides (Asteraceae) - the antimicrobial activity and essential oil composition of a Cape-Dutch remedy. J. Ethnopharmacol., v.88, p.137-143, 2003.
WEITZMAN, I.; SUMMERBELL, R.C. The dermatophytes. Clin. Microbiol. Rev., v.8, p.240-259, 1995.

YAMAGUCHI, H.; HIRATANI, T.; IWATA, K.; YMAMOTO, Y. Studies on the mechanisms of antifungal action of aculeacin A. J. Antibiotics, v.35, p.210-219, 1982.

Received for publication on $06^{\text {th }}$ May 2009 Accepted for publication on $18^{\text {th }}$ December 2009 